\title{
Comparative Study of Lipid and Fatty Acid Profile in Liver Tissues of Male and Female Silurus triostegus During the Catching Seasons
}

\author{
Semra Kaçar ${ }^{1}$ (D), Mehmet Başhan² (D)
}

Cite this article as: Kacar, S., \& Bashan, M. (2021). comparative study of lipid and fatty acid profile in liver tissues of male and female Silurus triostegus during the catching seasons. Aquatic Sciences and Engineering, 36(4), 166-174.

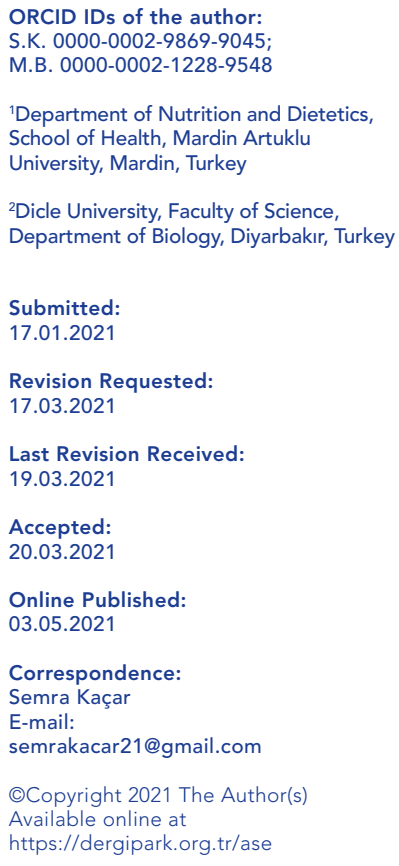

\begin{abstract}
In this study, seasonal variations of total fatty acid (FA), phospholipid (PL) and triacylglycerol (TAG) compositions in liver tissues of catfish (Silurus triostegus) were investigated. Samples of S. triostegus were obtained from Atatürk Dam Lake, Turkey, in two month periods during one year as from May. The major components were palmitic acid (16:0), stearic acid (18:0), oleic acid (18:1n-9), palmitoleic acid (16:1n-7), docosahexaenoic acid (DHA, 22:6n-3) and arachidonic acid (AA, 20:4n-6) in total lipid, 16:0, 18:0, 18:1n-9, eicosapentaenoic acid (EPA, 20:5n-3), DHA and AA in PL, 16:0, 16:1n7, 18:1n-9, linoleic acid (LA, 18:2n-6), AA, EPA, DHA and docosapentaenoic acid (22:5n-3) in TAG extracted from the liver of $S$. triostegus in all seasons. N-3/n-6 ratio was found 2.00-2.61 in females, $1.15-2.75$ in males in total lipid. The highest lipid content was found in May $(2.39 \%)$ in the females. In the males, the highest level was found in September (2.91\%). In TAG fraction, the component with the lowest ratio in both sexes' TAG is PUFA. In PL fraction, SFA, MUFA, and PUFA percentages were found at similar rates in both sexes in all months.
\end{abstract}

Keywords: Silurus triostegus, fatty acid, phospholipid, triacylglycerol, comparison, male, female, season, total lipid

\section{INTRODUCTION}

Mesopotamia catfish (S. triostegus) is a catfish species from the Siluridae family which is found in the Mesopotamia region namely Syria, Iraq, Iran, and Turkey. In S. triostegus living in the Atatürk Dam Lake, it was determined that egg laying started in May and continued until the end of June by utilizing parameters such as gonadosomatic index values and direct observation of gonads. Consequently, it can be said that the reproduction period is May, June, and July (Oymak et al., 2001).

Catfish meat is delicious, and has high protein content. It is a carnivore and aggressive species. Their nutrients usually are water insects and their larvae, worms, frogs, and tadpoles (Geldiay \& Balık 1996).
Today, there is a great interest in fish and fish oil due to the polyunsaturated fatty acids (PUFA) they contain. Analyzes usually constitute the fish muscle that forms the food. On the other hand, the fish liver, i.e., the main organ for longchain PUFA (LC-PUFA), has not been analyzed much (Ackman et al., 2002). Fish liver is the source of the essential oils for the prevention of problems related to vision and growth (Njinkoué et al., 2002). Moreover, livers of some fish species are used for muscle pain and rheumatism in Pakistan (Saify et al., 2003).

The liver is an important organ in terms of lipid metabolism. This organ also has an important role in the uptake, oxidation, and transformation of fatty acids (FA) and the supply of longchain highly unsaturated fatty acids to other tissues (Rincon-Sanchez et al., 1992). 
Phospholipids (PL) and triacylglycerides (TAG) have different roles in fish metabolism. Phospholipids are the main components of cell membrane and structure, and serve as precursors of eicosanoids with the C20 PUFA they contain. Meanwhile, TAG function as energy reserves (Sargent et al., 1995; Kiessling et al., 2001).

Fish oil and fatty acid composition are the most changed biochemical compounds according to the ecological factors and the physiological state of the fish. The total fat content and fatty acid composition in fish vary depending on species, sex, season, nutritional environment, nutrient difference, water temperature, water pollution, and whether the species are in the culture or natural form. Fat and fatty acids differ structurally in different fish species. If the same species of fish live in different geographical regions, they may differ in terms of fatty acid diversity (Ackman et al, 2002; Akpınar et al., 2009; Kayhan et al., 2014). This difference is also seen in different organs of the fish (Crowford et al., 1986; Suzuki et al., 1986).

Total, TAG, and PL fatty acids of $S$. triostegus liver have not studied before. Therefore, in this study, it was aimed to compare the seasonal changes of the total, TAG, and PL fatty acid contents of liver tissues of female and male individuals of $S$. triostegus living in Atatürk Dam Lake.

\section{MATERIALS AND METHODS}

Samples of S. triostegus fish species were gathered from the Atatürk Dam Lake in one year period by using a fishing net (between May, 2008 and March, 2009). On the same day, the caught fish samples were placed in heat-insulated protective containers filled with ice, and brought to the laboratory. The measurements of height and weight of the samples were made. Weight measurements were noted in grams, and height measurements were taken in $\mathrm{cm}$ using the fork length of the fish (Kaçar et al., 2016). In this study, three male and three female fish were used. The sexes of fish samples were detected. After determining the wet weights of the liver samples taken out, they were put in tubes and stored in the chloroform-methanol mixture at $-80^{\circ} \mathrm{C}$ until analysis.

\section{Lipid extraction and conversion of fatty acids to methyl esters} Liver samples homogenized in the chloroform-methanol mixture (Folch et al., 1957). The thin layer chromatography technique was used to fractionate the total lipids in the samples. For this purpose, the mixture of $30 \mathrm{~g}$ of silica gel and $50 \mathrm{ml}$ of pure water was applied as a thin layer to the plates of 20X20 size, and they were dried in an oven at $100{ }^{\circ} \mathrm{C}$ for one hour. Total lipid extracts of the samples were spotted onto the plates in a single row. The total lipids were run in a mixture of petroleum ether-diethyl ether-acetic acid (80:20:1). After drying the plates in the air, 27' dichlorofluorescein was sprayed to make the lipid fractions visible under the UV lamp. The bands of phospholipids and triacylglycerol fractions that were determined by means of standards were scraped and transferred to the reaction tubes. To each fraction, $3 \mathrm{ml}$ of methanol and 3-5 drops of sulfuric acid were added dropwise, and they were all heated at $85^{\circ} \mathrm{C}$ under reflux for 2 hours (Stanley-Samuelson and Dadd,1983). The solution was extracted with methyl esters using hexane. Gas chromatography instrument with a FID detector was used for the analysis of fatty acid methyl esters.

\section{Gas chromatography conditions}

Fatty acid analyses of the oil samples converted to methyl esters were performed by using flame ionization detector and DB-23 capillary column in HP6890 model Gas Chromatography device. The features used were as follows. Detector temperature: $280^{\circ} \mathrm{C}$, injector temperature: $270{ }^{\circ} \mathrm{C}$, and injection: split-model 1/20. Gas flow rates were; carrier gas: $2.8 \mathrm{ml} / \mathrm{min}$ (constant flow model), hydrogen: $30 \mathrm{ml} / \mathrm{min}$, and air: $300 \mathrm{ml} / \mathrm{min}$. Column (oven) temperature: at $130{ }^{\circ} \mathrm{C}$, stand-by time 1 minute; to $170{ }^{\circ} \mathrm{C}$ with $6.5^{\circ} \mathrm{C} / \mathrm{min}$, to $215^{\circ} \mathrm{C}$ with $2.75^{\circ} \mathrm{C} / \mathrm{min}$, standby time 12 minutes; to $230^{\circ} \mathrm{C}$ with $40^{\circ} \mathrm{C} / \mathrm{min}$, standby time 3 minutes; total analysis time: 38.8 minutes. For example, 1 microliter was injected into the device. A mixture of methyl esters of fatty acids was used as the standard in the detection of fatty acids. Chromatograms of fatty acids methyl esters and total fatty acids were obtained from the computer by the software HP 3365 Chem Station.

\section{Evaluation of data}

SPSS 16 computer program was used to compare fatty acid percent rates. All data obtained in our study were obtained from the average of three replicates. In the gas chromatographic analysis of fatty acid methyl esters, three samples of each period were injected separately, and the three values of the same fatty acid were averaged. Comparison of fatty acid percentages was made by one-way analysis of variance. Differences were determined by Tukey HSD test. As a result of the statistics, it was accepted that the differences were significant when the data were $p<0.05$.

\section{RESULT AND DISCUSSION}

\section{Lipid content}

The quantity of total lipids ranging from 1.29 to $2.39 \%$ (breeding period) in S. triostegus females decreased in July, September, and January. In male fish, this ratio was found between 0.50 $2.91 \%$ (post-breeding period). In males, the amount of lipid decreased significantly after September, in November and January. It increased in March (pre-breeding period) and in May (breeding period) (Table 1).

In freshwater fish, the lipid content of the liver varies depending on the season, feeding cycle, and reproductive status (Ackman et al., 2002).

Table 1. Total lipid of liver tissue of female and male $S$.
triostegus.

\begin{tabular}{llc}
\hline & \multicolumn{2}{c}{ Total lipid (\%) } \\
\hline & Female & Male \\
\hline May & $2.39 \pm 0.65 a$ & $2.14 \pm 0.45 a$ \\
July & $1.78 \pm 0.38 b$ & $1.04 \pm 0.12 b$ \\
September & $1.61 \pm 0.40 b$ & $2.91 \pm 0.13 a$ \\
November & $2.03 \pm 0.35 a$ & $0.50 \pm 0.07 c$ \\
January & $1.29 \pm 0.21 b$ & $0.60 \pm 0.14 c$ \\
March & $1.74 \pm 0.41 b$ & $2.09 \pm 0.52 a$ \\
\hline \multirow{2}{*}{ Superscript letters $(a, b, c)$ denote significant differences $(p<0.05)$ in lipid } \\
content among months.
\end{tabular}


In the current study, it was found that liver lipid content decreased in the reproductive period of July. The decrease in total lipid and total fatty acid levels in the liver and muscles of the fish in the reproductive period shows that they obtain the energy they need from these lipids. During the reproductive period, the lipids in the liver and muscle are mobilized to the gonad for gonad development (Castell et al., 1972).

In previous studies, the liver lipid content of Cyprinus carpio increased in the spring (Kminkova et al., 2001; Akpınar, 1986a). Kandemir \& Polat (2007) found the maximum total lipid amount in the liver of Oncorhynchus mykiss in the autumn season. In the present study, the highest lipid content of female fish was found in May in accordance with the previous studies.

The amount of lipid in the S. triostegus males decreased significantly in November and January, and increased in March and May. Jangaard et al., (1967) reported that seasonal changes in lipid level in liver and other organs are caused by irregular seasonal changes in fish feeding and water temperature.

In our study, the amount of lipid increased in both sexes in the autumn months, which was the post-reproductive period. Stored lipids vary during the breeding and feeding period. Especially when fish find enough food, they can control their reproduction and lipid storage period. The lipid storage cycle is directly related to the abundance of food. Lipid variation is high throughout the year if nutrients are abundant, whereas lipid variation is low if nutrients are scarce (Kluytmans \& Zandee, 1973, Ackman \& Eaton, 1976, Kinsella et al., 1977, Mute et al., 1989).

\section{The FA composition of total lipid}

The total fatty acid content of female and male $S$. triostegus liver tissue is given in Table 2. The highest saturated fatty acids (SFA) in females were found in the summer whereasin males, they were found in spring which is the reproductive period. The lowest SFA was found in January in both sexes. The SFA was found to have 16:0 and 18:0 most commonly. The $16: 0$ ratio with saturated fatty acids decreased in males and females in January and in the pre-breeding period in March In males, both components were found to be the highest in May, which is in the breeding period. The 18:0 were highest in females during November, yet no statistically significant difference was found in other seasons. This fatty acid in males showed fluctuations throughout the year. In males and females, monounsaturated fatty acids (MUFA) in liver tissue increased in January.

The MUFA and 18:1n-9 ratio was high in January and March, and decreased in September in both males and females. In September, the amount of 16:1n-7 in females reached the lowest value. This fatty acid did not show a significant change except June and September. The highest value for males was found in January. Also, 18:1n-9 did not differ in females in all seasons. In males, it is low in May and September and close to each other. The PUFA in both sexes was found to be high in September. It fell in females in May and in July in males. The 20:5n-3, 22:5n-3, and 22:6n-3 are major n-3PUFA while $18: 2 n-6$ and $20: 4 n-6$ are dominant n-6PUFA. Moreover, the 20: 5n-3 was found to decrease in September after the breeding period, and has the highest value in winter in female S. triostegus liver tissue. It was also observed that it decreased in July and increased in May in males. In May, when the arachidonic acid was the lowest in females, it was the highest in males. Docosahexaenoic acid (DHA) increased in both sexes in July and September. In females, in May, July, and November the highest SFA, in January the highest PUFA and the lowest MUFA was found while in males, in September the highest PUFA and in July, November, January, and March the highest MUFA was determined. The dominant fatty acids throughout the year are 16:0 from SFA, 18:1n-9 from MUFA, and DHA from PUFA. $\mathrm{N}-3 / \mathrm{n}-6$ ratio was found $2.00-2.61$ in females and $1.15-2.75$ in males. In both sexes, the highest value was determined in the same month, and it was close to each other.

Fish are not only important protein sources but also contain nutritionally valuable lipids. Analyzes usually focus on the fish muscle that forms the food. But the fish liver is the main organ of long-chain PUFA and has not been analyzed much (Ackman et al., 2002).

In fish liver, lipids major fatty acids are similar to the ones in fish muscle. Most of the fish that have been studied have 16:0 most among the saturated fatty acids, 18:1n-9 among the monounsaturated, and 22:6n-3 among the polyunsaturated (Kminkova et al., 2001; Uysal et al., 2006; Akpınar et al., 2009; Njinkoué et al., 2002; Aras et al., 2003b). Similar results were found in S. triostegus liver. However, quantitative fatty acid content in the liver varies. In accordance with the present study, in the previous studies, 14:0 and 18:0 found least among the saturated fatty acids, 16:1n-7 among the monounsaturated fatty acids, $18: 2 n-6$ and $18: 3 n-3$ among the highly unsaturated fatty acids, $20: 3 n-6$ and 20:4n-6 acids which are the precursors of eicosanoids (Tufan et al., 2013; Misir et al., 2016; Kaçar \& Başhan, 2017).

Sander lucioperca's n-3 fatty acids increased most in November when the temperature fell (Uysal et al., 2006). In both sexes of $S$. triostegus, PUFA increased in the autumn and winter when the temperature fell (Kaçar et al., 2016).

In the previous studies, in line with the current research, it was observed that long-chain unsaturated fatty acids have changed more than saturated fatty acids. It was concluded that gonad development and breeding periods had directly an effect on these changes (Akpınar, 1986b).

The data indicate that the ratio of $n-3 / n-6$ in total lipids of the liver may be different in both sexes. This depends on the ratios of 18:3n-3, 20:5n-3, 22:5n-3, and 22:6n-3, forming n-3PUFA and 18:2n-6, 20:3n-6, and 20:4n-6, forming n-6PUFA.

In the current investigation, it was determined that the fatty acid content of fish liver lipids is affected by the sex and the season, thus, the reproductive period.

\section{The FA composition of TAG fraction}

Table 3 shows the TAG fatty acid content of male and female S. triostegus liver. Palmitic acid and therefore the SFA ratio in males increased in September, which is the post-breeding period, and decreased in March, just before the breeding season. There was no significant difference in females for 16:0 throughout the year. 


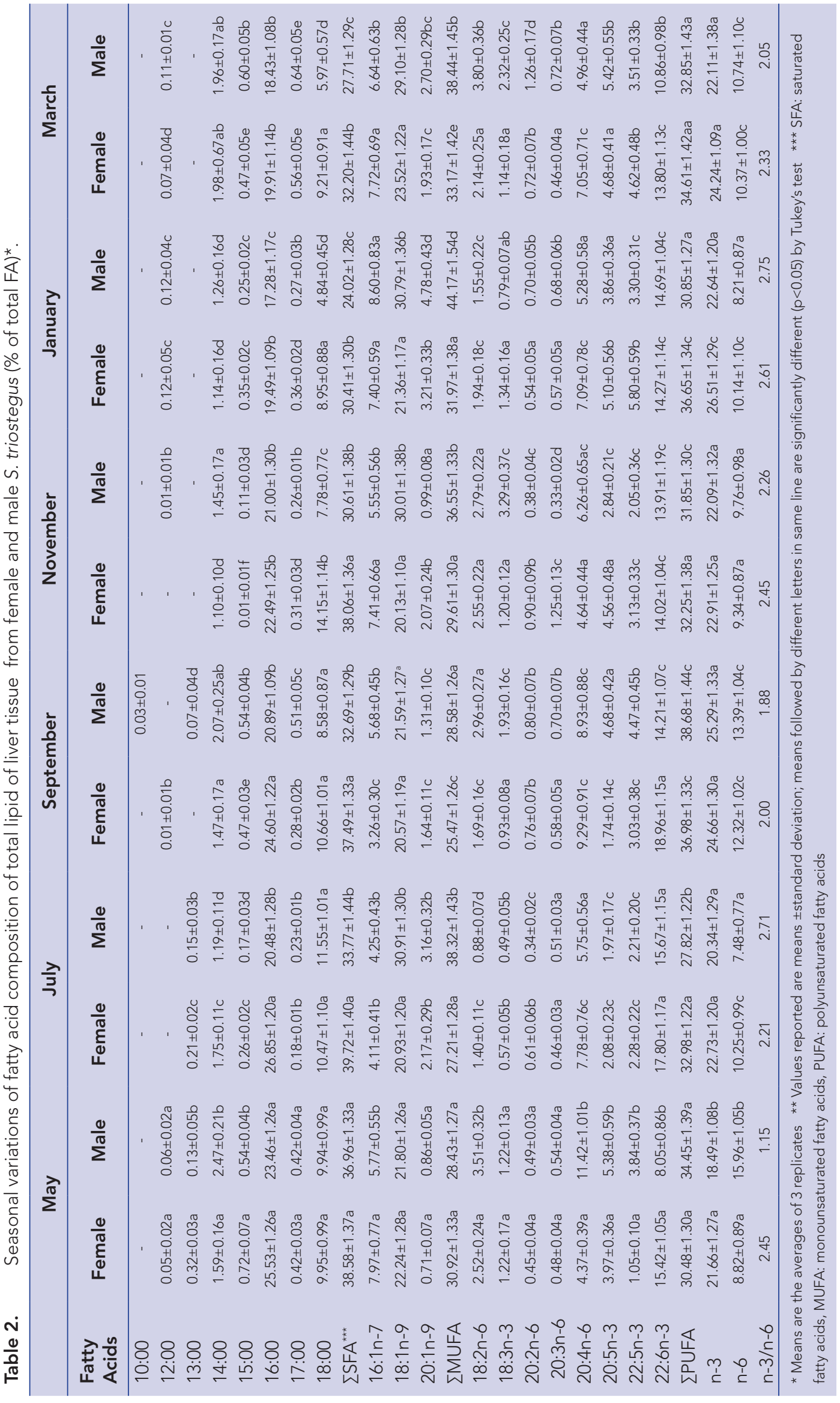




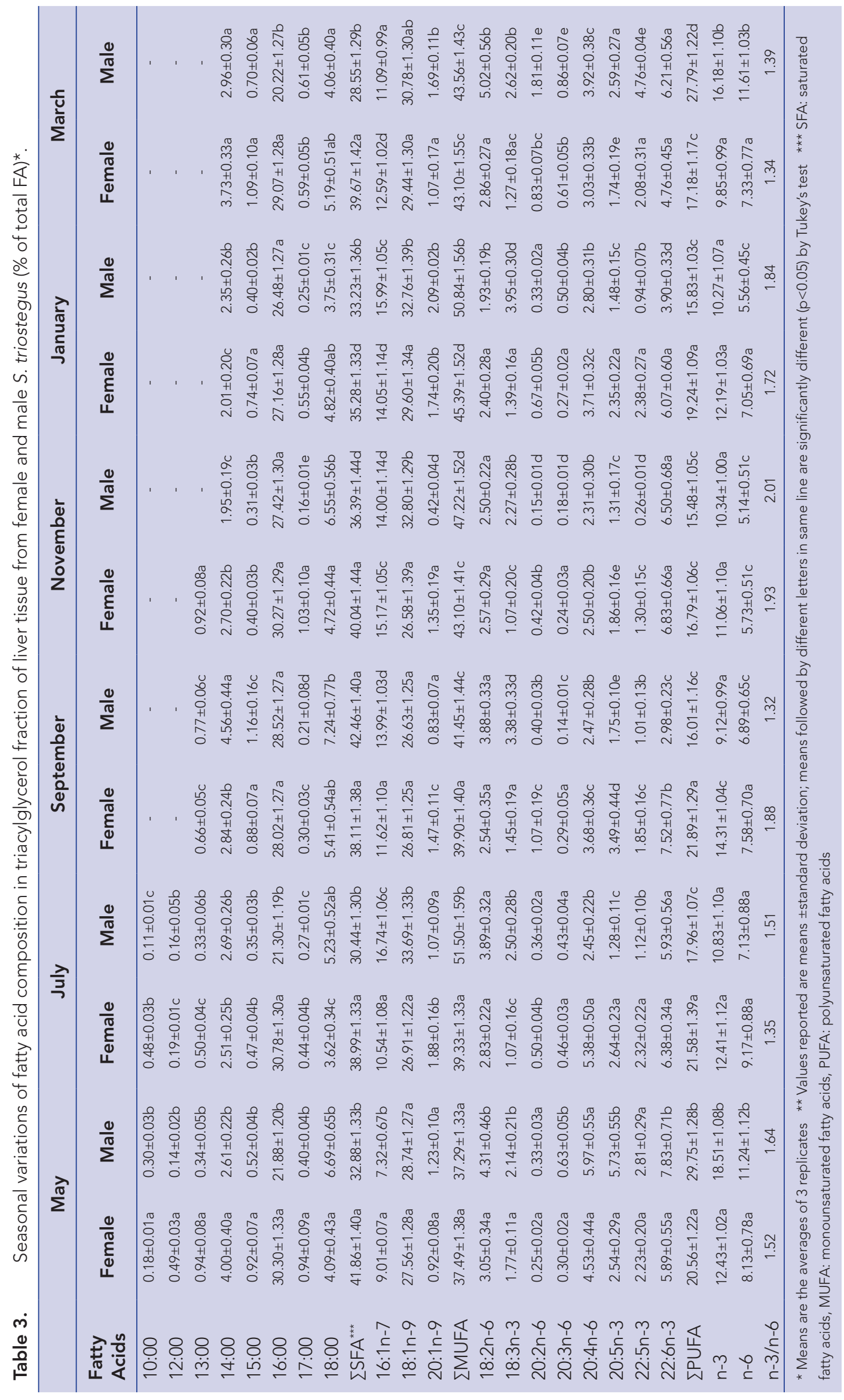




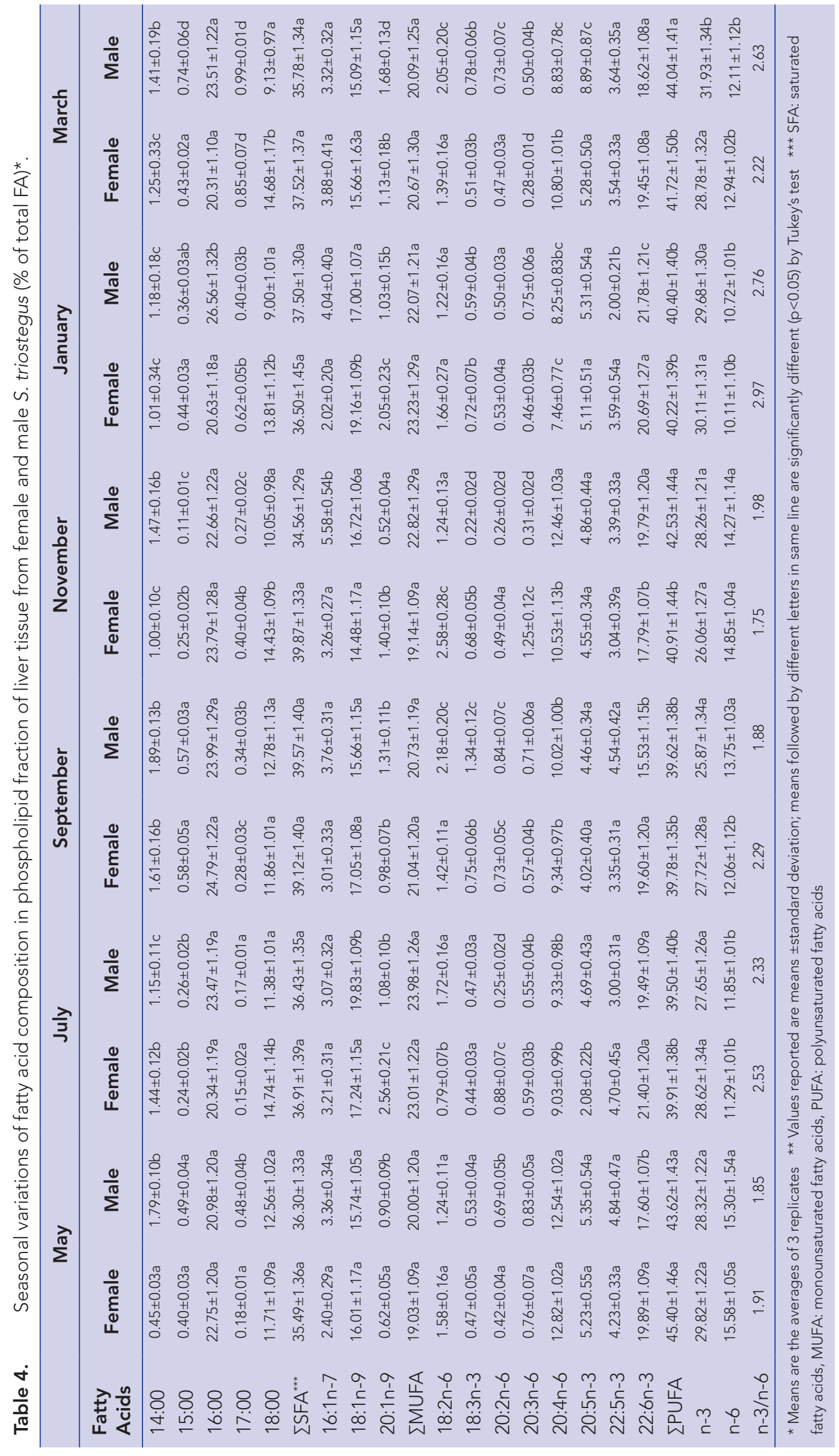


In males, it was low in May, July, and March, and it was close to each other,while in September, November, and January it was high and close to each other. Palmitoleic acid and MUFA ratio were found to be highest in females in November and January and in males in July and January. These components decreased in both sexes in May, which is the reproductive period. The 18:1n9 and $16: 1 n-7$ are the most frequently detected MUFA in both sexes. In addition, 20:1n-9 were detected in both sexes, albeit in small amounts.

In the female TAG fraction, SFA was found most in May, and MUFA was found in November, January, and March. The ratio of these components in the other two months is similar. In males, MUFA was found in all months most commonly in males except for September. The component with the lowest ratio in both sexes' TAG is PUFA. It is noteworthy that MUFA ratios are higher in this fraction. In females, the PUFA ranged 16.79 to $21.89 \%$ and in males ranged from 15.48 to $29.75 \%$ through the year. The $20: 4 n-$ 6 and DHA were found as major PUFA. The ratio of $n-3 / n-6$ in the liver TAG fraction of $S$. triostegus was 1.34-1.93 in females and $1.32-2.01$ in males. The highest $n-3 / n-6$ ratio was determined in November in both sexes.

Fat-free fish store $50-80 \%$ of their fat in their livers in the form of TAG, which are good sources for fat-soluble vitamins, especially A and D vitamins (Jacquot, 1961).

In fish caught in nature, in TAG mostly monoenes, then saturated followed by PUFA are found (Henderson \& Tocher, 1987). Based on this, it has been found that fish species accumulate mainly SFA and MUFA as stored lipids (Pinela et al., 2009). The reason for the high rate of monoenes in triacylglycerol is that among the components in this group, the ratio of 18:1-9 is higher. In addition, $n$-3HUFAs were found to be low in this fraction since the amount of n-3 components such as 20:5n-3 and 22:6n-3 was low (Cejas et al., 2003).

Fatty acids such as palmitic acid, 16:1n-7, and 18:1n-9 are found to be excessively present in storage lipids (Ackman 1967). In the present research, MUFA were found in the liver TAG of both sexes most, then SFA followed by PUFA were found. Similar results were found by Kozlova \& Khotimchenko (2000) as well. In May (reproduction period) the percentage of MUFA decreased. Their amounts may be reduced because these components are mobilized to the gonad for reproduction.

In Comephorus baicalensis, MUFA were found to be the most, SFA next, and then PUFA the least. Among the monounsaturated fatty acids 18:1-9 were found most. The 16:0 was determined most within the SFA group. Other major fatty acids are 16:1n-7, 18:1n-7, and 20:5n-3(Kozlova \& Khotimchenko, 2000). Ackman et al., (2002) identified the 16:0, 18:1n-9, 16:1n-7, 18:2n-2, 18:3n-3, $20: 4 n-6,20: 5 n-3$, and $22: 6 n-3$ as the major fatty acids. This finding is consistent with the findings of the current study as well.

\section{The FA composition of PL fraction}

In the liver PL fraction of S. triostegus, the seasonal rates of SFA was $35.49-39.87 \%$ in females and $34.56-39.57 \%$ in males, MUFA was $19.03-23.23 \%$ in females and $20.0-23.98 \%$ in males, and PUFA was $39.78-45.40 \%$ in females and $39.50-44.04 \%$ in males. As can be seen from the data, SFA, MUFA, and PUFA percentages were found at similar rates in both sexes in all months. Similarly, the percentages of major components such as 16:0, 18:1n-9, 20:4n-6, 20:5n-3, and 22:6n-3 did not differ within months. In both sexes of $S$. triostegus, PUFA found most, SFA next, and MUFA least, in all seasons. In this fish, the ratio of $n-3 / n-6$ was $1.75-2.97$ in females and $1.85-2.76$ in males. In both sexes, the $n-3 / n-6$ rate increased in January (Table 4).

The SFA rate is reduced by exposure to low temperature, yet the proportion of unsaturated fatty acids increases (Jobling and Bendiksen 2003). The increased unsaturated fatty acids are either monoene or polyene (Wallaert and Babin, 1994, Fodor et al., 1995, Logue et al., 2000).

The increase of the ambient temperature reduces the accumulation of $n-3$ in PL (Delgado et al., 1994). The change in the salinity and temperature of water affects the length and the degree of unsaturation of the fatty acids in the membrane PL in poikilotherms. (Cordier et al., 2002).

In this study, it was observed that PUFA decreased in July and September when the temperature was high.

The 16:0 is dominant in SFA and its ratio in fish tissues is not affected by nutrition (Ackman et al., 1975) Ackman et al., (2002) detected that 16:0, 18:0, 18:1n-9, 16:1n-7, 20:4n-6, 20:5n-3, and 22:6n-3 were dominant in the $\mathrm{PL}$ fraction. The results are consistent with the results of the current study. Buzzi et al., (1997) stated that in the liver of Exos lucius, linolenic acid was converted into EPA and DHA. This transformation is very important in fish physiology (Arts et al., 2001).

AA was found as major $n-6$ PUFA in both sexes in all seasons. AA is the precursor molecule for the synthesis of thromboxane and prostaglandins (Bell et al., 1994).

In the case of migration and gonad development, the amount of EPA and DHA is mostly maintained compared to MUFA. The fact that the percentages of these two components do not change much is necessary to maintain the cell membrane structure and function (Sargent et al., 1995, Cejas et al., 2004).

\section{CONCLUSION}

In the present study, it was found that the amount of DHA and EPA in both sexes did not differ much by season either. PUFA was detected most in the PL fraction in both sexes. According to these results, it can be said that the lipid metabolism of the fish changes depending on the spawning and season.

Conflict of interests: The authors declare that they have no conflict of interest.

\section{Ethics committee approval:-}

Funding: This study was financed by the Dicle University Scientific Research Foundation (DUAPK-08-FF-07).

\section{Acknowledgements:-}

\section{Disclosure: -}




\section{REFERENCES}

Ackman, R.G. (1967). Characteristics of the fatty acid composition and biochemistry of some fresh-water fish oils and lipids in comparison with marine oils and lipids. Comparative Biochemistry and Physiology, 22,907-922. [CrossRef]

Ackman, R.G., Eaton, C.A, \& Linne, B.A. (1975). Differentiation of freshwater characteristics of fatty acids in marine specimens of the Atlantic sturgeon (Acipenser oxyrhynchus). Fishery Bulletin, 73,838-845.

Ackman, R.G, \& Eaton, C.A. (1976). Fatty acid composition of the decapod shrimp, Pandulus borealis, in relation to that of the euphasiid, Meganyctiphanes noruegica. Journal of the Fisheries Research Board of Canada, 33,1634-1638. [CrossRef]

Ackman, R.G., Mcleod, C., Rakshit, S, \& Mısra, K.K. (2002). Lipids and fatty acids of five freshwater food fishes of India. Journal of Food Lipids, 9 (2), 127-145. [CrossRef]

Akpınar, M.A. (1986a). Cyprinus carpio L. (Osteichthyes:Cyprinidae)'nın karaciğer ve kasındaki total lipit ve total yağ asidinin mevsimsel değişimi. C.Ü. Fen Edebiyat Fakültesi Fen Bilimleri Dergisi, 4,33-42.

Akpınar, M.A. (1986b). Cyprinus carpio L. (Osteichthyes:Cyprinidae)'nın karaciğer yağ asitlerinin mevsimsel değişimi. Doğa TU Biyoloji, 10(3),232-239.

Akpınar, M.A., Görgün, S, \& Akpınar, A.E. 2009. A comparative analysis of the fatty acid profiles in the liver and muscles of male and female Salmo trutta macrostigma. Food Chemistry, 112,6-8. [CrossRef]

Aras, N.M., Haliloğlu, H.I., Ayık, Ö, \& Yetim, H. (2003). Comparison of fatty acid profiles of different tissues of mature trout (Salmo trutta labrax, Pallas, 1811) caught from Kazandere Creek in the Çoruh Region, Erzurum, Turkey. Turkish Journal of Veterinary and Animal Science, 27,311-316.

Arts, M.T., Ackman, R.G, \& Holub, B.J. (2001). Essential fatty acids in aquatic ecosystems: A crucial link between diet and human health and evolution. Canadian Journal of Fisheries and Aquatic Science, 58,122-137. [CrossRef]

Bell, J.G., Tocher, D.R., McDonald, F.M, \& Sargent, J.R. (1994). Effect of supplementation with $(20: 3 n-6),(20: 4 n-6)$ and $(20: 5 n-3)$ on the production of prostaglandin-e and prostaglandin-f on the 1-series, 2-series and 3-series in turbot (Scophthalmus maximus) brain astroglial cells in primary culture. Biochimica et Biophysica Acta, 1211,335-342. [CrossRef]

Buzzi, M., Henderson, R.J, \& Sargent, J.R. (1997). The biosynthesis of docosahexaenoic acid [22:6(n-3)] from linolenic acid in primary hepatocytes isolated from wild Northern pike. Journal of Fish Biology, 51(1),1197-1208. [CrossRef]

Castell, J.D., Lee, D.J, \& Sinnhuber, R.O. (1972). Essential fatty acids in the diet of rainbow trout (Salmo gairdneri): Lipid metabolism and fatty acid composition. The Journal of Nutrition, 102, 77-86. [CrossRef]

Cejas, J.R., Almansa, E., Villamandos, J.E., Badia, P., Bolanos, A, \& Lorenzo, A. (2003). Lipid and fatty acid composition of ovaries from wild fish and ovaries and eggs from captive fish of white sea bream (Diplodus sargus). Aquaculture, 216(1-4), 299-313. [CrossRef]

Cejas, J.R., Almansa, E., Jerez, S., Bolanos, A., Samper, M, \& Lorenzo, A. (2004). Lipid and fatty acid composition of muscle and liver from wild and captive mature female broodstocks of white seabream, Diplodus sargus. Comparative Biochemistry and Physiology, 138B,91-102. [CrossRef]

Cordier, M., Brichon, G., Weber, J.M, \& Zwingelstein, G. (2002). Changes in the fatty acid composition of phospholipids in tissues of farmed sea bass (Dicentrarchus labrax) during annual cycle. Roles of environmental temperature and salinity. Comparative Biochemistry and Physiology, 133B,281-288. [CrossRef]

Crowford, R.H., Cusack, R.R, \& Parlee, T.R. (1986). Lipid content and energy expenditure in the spawning migration of alewife (Alosa pseudoharengus) and bluelback herring (Alosa aestivalis). Canadian Journal of Zoology, 64,1902-1907. [CrossRef]
Delgado, A., Estevez, A., Hortelano, P, \& Alejandre, M.J. (1994). Analyses of fatty acids from different lipids in liver and muscle of sea bass (Dicentrarchus labrax L.). Influence of temperature and fasting. Comparative Biochemistry and Physiology, 108A,673-680. [CrossRef]

Fodor, E., Jones, R.H., Buda, C., Kitajka, K., Dey, I, \& Farkas, T. (1995). Molecular architecture and biophysical properties of phospholipids during thermal adaptation in fish: An experimental and model study. Lipids, 30(12), 1119-1126. [CrossRef]

Folch, J., Lees, M, \& Sladane-Stanley, G.H.A. (1957). Simple method for the isolation and purification of total lipids from animal tissues. The Journal of Biological Chemistry, 226, 497-509. [CrossRef]

Geldiay, R, \& Balık, S. (1996). Türkiye tatlısu balıkları. Ege Üni. Su Ürünleri Fak. Yay. No: 46 (II. Baskı), İzmir.

Henderson, R.J, \& Tocher, D.R. (1987). The lipid composition and biochemistry of freshwater fish. Progress in Lipid Research, 26, 281347. [CrossRef]

Jacquot, R. 1961. Organic constituents of fish and other aquatic animals. Fish as food. Borgstrom. G. (Ed.). Academic Press, p. 145-209. New York and London. [CrossRef]

Jangaard, R.G., Ackman, R, \& Sipos, J.C. (1967). Seasonal changes in fatty acid composition of cod liver, flesh, roe and milt lipids. Journal of the Fisheries Research Board of Canada, 24,613-627. [CrossRef]

Jobling, M, \& Bendiksen, E.A. (2003). Dietary lipids and temperature interact to influence tissue fatty acid compositions of Atlantic salmon, Salmo salar L. parr. Aquaculture Research, 34,1423-1441. [CrossRef]

Kaçar, S., Başhan, M. \& Oymak, S.A. (2016). Effect of seasonal variation on lipid and fatty acid profile in muscle tissue of male and female Silurus triostegus. Journal of Food Science and Technology, 53, 2913-2922. [CrossRef]

Kaçar, S, \& Başhan, M. (2017). Variations in the fatty acid compositions of the liver and gonad tissue of spiny eel (Mastacembelus mastacembelus) from Atatürk Dam Lake. Turkish Journal of Biochemistry, 42(6),617-623. [CrossRef]

Kandemir, Ş, \& Polat, N. (2007). Seasonal variation of total lipid and total fatty acid in muscle and liver of rainbow trout (Oncorhynchus mykiss W. 1792) reared in Derbent Dam Lake. Turkish Journal of Fisheries and Aquatic Science, 7,27-33.

Kayhan, H., Başhan, M, \& Kaçar, S. (2014). Seasonal variations in the fatty acid composition of phospholipids and triacylglycerols of brown trout. European Journal of Lipid Science and Technology, 117(5), 738744. [CrossRef]

Kiessling, A., Pickova, J., Johansson, L., Asgard, T., Storebakken, T, \& Kiessling, K.H. (2001). Changes in fatty acid composition in muscle and adipose tissue of farmed rainbow trout (Oncorhynchus mykiss) in relation to ration and age. Food Chemistry, 73, 271-284. [CrossRef]

Kinsella, J.E., Shimp, J.L, \& Mai, J. (1977). Fatty acid content and composition of fresh water finfish. Journal of the American Oil Chemists' Society, 54,424-429. [CrossRef]

Kluytmans, J.H.F.M, \& Zandee, D.I. (1973). Lipid metabolism in the Northern pike (Exos lucius L.) I. The fatty compositions of the Northern pike. Comparative Biochemistry and Physiology, 44B,451458. [CrossRef]

Kminkova, M., Winterova, R, \& Kucera, J. (2001). Fatty acids in lipids of carp (Cyprinus carpio) tissues. Czech Journal of Food Science, 19,177-181. [CrossRef]

Kozlova, T.A, \& Khotimchenko, S.V. (2000). Lipids and fatty acids of two pelagic cottoid fishes (Comephorus spp.) endemic to Lake Baikal. Comparative Biochemistry and Physiology, 126B,477-485. [CrossRef]

Logue, J.A., DeVries, A.L., Fodor, E, \& Cossins, A.R. (2000). Lipid compositional correlates of temperature-adaptive interspeciecific differences in membrane physical structure. Journal of Experimental Biology, 203,2105-2115.

Misir, G.B., Tufan, B, \& Köse, S. (2016). Variations in Total Lipid and Fatty Acid Contents of Edible Muscle, Liver, and Roes of Spotless Shad, 
Alosa Immaculata, During Catching Season in Black Sea, Journal of Aquatic Food Product Technology, 25(1),2-14. [CrossRef]

Mute, P., Agren, J.J., Lindovist, O.V, \& Hanninen, O. (1989). Fatty acid composition of vendace (Coregonus albula L.) muscle and its plankton feed. Comparative Biochemistry and Physiology, 92B,75-79. [CrossRef]

Njinkoué, J-M., Barnathan, G., Miralles, J., Gaydou, E.M, \& Samb, A. (2002). Lipids and fatty acids in muscle, liver and skin of three edible fish from the Senegalese coast: Sardinella maderensis, Sardinella aurita and Cephalopholis taeniops. Comparative Biochemistry and Physiology, 131B,395-402. [CrossRef]

Oymak, S.A., Solak, K, \& Ünlü, E. (2001). Some biological characteristics of Silurus triostegus Heckel, 1843 from Atatürk Dam Lake (Turkey). Turkish Journal of Zoology, 25,139-148.

Pinela, S., Quintella, B.R., de Almeida, P.R, \& Lança, M.J. (2009). Comparison of the fatty acid profile of muscle neutral lipids and phospholipids of up-river anadromous sea lamprey (Petromyzon marinus L.) from three Portuguese River Basins. Scientia Marina, 73,785-795. [CrossRef]

Rincon-Sanchez, A.R., Hernandez, A., Lopez, M.L, \& Mendoza-Figueroa, T. (1992). Synthesis and secretion of lipids by long-term cultures of female rat hepatocytes. Biology of the Cell, 76,131-138. [CrossRef]

Saify, Z.S., Akhtar, S., Khan, K.M., Perveen, S., Ayattollahi, S.A.M., Hassan, S., Arif, M., Haider, S.M., Ahmad, F., Siddiqui, S, \& Khan, M.Z. (2003). A study on the fatty acid composition of fish liver oil from two marine fish, Eusphyra blochii and Carcharhinus bleekeri. Turkish Journal of Chemistry, 27,251-258

Sargent, J.R., Bell, J.G., Bell, M.V., Henderson, R.J, \& Tocher, D.R. (1995). Requirements criteria for essential fatty acids. Journal of Applied Ichthyology, 11,183-198. [CrossRef]

Stanley-Samuelson, D.W, \&Dadd, R.H. (1983). Long-chain polyunsaturated fatty acids: patterns of occurrence in insects. Journal of Food Science and Technology, 13, 549-558. [CrossRef]

Suzuki, H., Okazaki, K., Hayakawa, S., Wada, S, \& Tamura, S. (1986). Influnece of commercial dietary fatty acids on PUFA of cultured freshwater fish and comparison with those of wild fish of the same species. Journal of Agricultural and Food Chemistry, 34,58-60. [CrossRef]

Tufan, B., Koral, S, \& Köse, S. (2013). The Variations in Proximate Chemical Composition and Fatty Acid Profile in Different Parts of the Thornback Ray (Raja clavata) Caught from Black Sea, Turkey, Journal of Aquatic Food Product Technology, 22(1),83-95. [CrossRef]

Uysal, K., Yerlikaya, A., Aksoylar, M.Y., Yöntem, M, \& Ulupinar, M. (2006). Variations in fatty acids composition of pikeperch (Sander lucioperca) liver with respect to gonad maturation. Ecology of Freshwater Fish, 15,441-445. [CrossRef]

Wallaert, C, \& Babin, P.J. (1994). Thermal adaptation affects the fatty acid composition of plasma phospholipids in trout. Lipids, 29,373-376. [CrossRef] 